\title{
Combination of Plant Growth Promoting Rhizobacteria and Biopesticides: An Effective Means of Suppressing Pod Borer Complex in Mungbean
}

\author{
Snehangshu Das ${ }^{1}$, Swarnali Bhattacharya ${ }^{1}$ and Tapamay Dhar ${ }^{2 *}$ \\ ${ }^{1}$ Department of Agricultural Entomology, Institute of Agriculture, Visva Bharati University, \\ Sriniketan-731236, Bolpur, Birbhum, West Bengal, India, \\ ${ }^{2}$ Regional Research Sub Station (Old Alluvial Zone), Uttar Banga Krishi Viswavidyalaya, \\ Mathurapur-732203, Malda, West Bengal, India
}

*Corresponding author

\section{A B S T R A C T}

\section{Keywords}

Bio-control agents, Helicoverpa armigera, Maruca testulalis, Vigna radiata

\section{Article Info}

Accepted:

12 October 2019

Available Online:

10 November 2019
An experiment was conducted to evaluate the effect on seed biopriming in integration of bio-pesticides on the infestation of pod borer complex of mungbean in the Institutional farm of Institute of Agriculture, Visva Bharati University during 2014-2015. Seed bio-priming was done by Pseudomonas fluorescence and other bio-agents, where the bio-pesticides used were Beauveria bassiana, Verticillium lecanii and Metarhizium anisopliae. Studies on different biochemical parameters of the plants were made to highlight on the impact on pod borer infestation. The results of the experiment suggested that seed bio-priming with Pseudomonas fluorescence along with consecutive spray of Beaveria bassiana and Verticillium lecanii were found effective to reduce the infestation of pod borer complex upto $75.02 \%$ as compared to untreated check. It also reduced the percentage of damaged pods upto $11.86 \%$. However, Pseudomonas fluorescence had a clear impact towards enhancement of phenol and ortho-dihydroxy phenol content along with peroxidise activities in mungbean leaf thus imparting resistance to pod borer complex.

\section{Introduction}

Mungbean Vigna radiata (L.) Wilzcek, an important legume crop is gaining importance due to its wide adaptability in different climatic conditions, tolerance to water stress and salinity, capacity of fixing atmospheric nitrogen and checking the soil nutrient depletion (Pataczek et al., 2018). It is a rich source of protein, carbohydrate and other micronutrients in daily diet and used as ironrich whole food source for baby food (Nair et al., 2013). India is one of the largest producers of mungbean in the world with a production of 1.90 million tonnes of mungbean grains having acreage of 4.07 million hectares (Anonymous, 2018). However, the country imports mungbean every year due to huge gap 
between demand and supply. The crop suffers from low productivity due to lack of good varieties, poor agronomic management practices and improper crop protection measures (Singh et al., 2015).

A wide array of insect-pest species infests the crop on regular intervals, which results into huge yield loss upto 38.06\% (Lal 1985; Duraimurugan and Tyagi, 2014). Pod borer complex such as gram pod borer Helicoverpa armigera and spotted pod borer Maruca tetulalis are two most noxious pests of the crop infesting in both vegetative and reproductive stage.

They cause a yield loss upto $36.14 \%$ in case of severe infestation (Umbarkar et al., 2011). Growers are mostly relying upon chemical insecticidal measures, which in turn result into resistance and resurgence development as well as environmental hazards (Mahamood et al., 2016).

Microbial bio-pesticides, as an alternative to chemical insecticides are very safe to environment and natural enemies of crop pest. However, it has a disadvantage due to its limited persistency in adverse environmental conditions (Maina et al., 2017).

Now a days, plant growth promoting rhizobacteria and other beneficial soil microbes are used to induce systemic resistance against insect herbivores by enhancing biosynthesis of secondary metabolites and activities of plant defense enzymes (Murugan and Dhandapani, 2007; Pangesti et al., 2017; Rashid and Chung, 2017).

An attempt was made to evaluate the efficacy of the bio-pesticides in integration with seed priming of mungbean by Pseudomonas fluorescence and other growth promoting bioagents in order to achieve sufficient control against pod borer complex without using chemical insecticides.

\section{Materials and Methods}

The field experiment was conducted during Post Kharif season of 2015 and 2016 in Agricultural Farm of Institute of Agriculture, Visva-Bharati located at Birbhum district of West Bengal having latitude and longitude $23^{\circ} 40.182 \mathrm{~N}$ and $87^{\circ} 39.555^{\prime} \mathrm{E}$ respectively. The experimental site is situated in the subhumid sub-tropical lateritic belt of West Bengal.

The experiment was carried out in Randomized Block Design (RBD) having seven treatments with four replications. The variety of mungbean, PDM 139 was sown on $05^{\text {th }}$ of September in both the year with a plot size of $4 \mathrm{~m} \times 3 \mathrm{~m}$. Row to row distance was maintained in $30 \mathrm{~cm}$. The treatments are mentioned in Table 1.

The bio-inoculum for trials were prepared and supplied by the Department of Plant Pathology of Uttar Banga Krishi Viswavidyalaya with required population in formulation $\left(10^{8}\right.$ for each Pseudomonas, Phosphate Solubilizing Bacteria, Azotobacter and Rhizobium) following standard protocol (Park et al., 2005). Seeds of mungbean were primed with all these bio-inoculant in 1:1 ratio @ $5 \mathrm{~g} / \mathrm{kg}$ of seed for 30 minutes. Bio-primed seeds of mungbean (variety: PDM 139) were sown for the experimental purpose. Recommended agronomic practices were followed throughout the crop growth period (Bhowmick et al., 2008). However, nitrogen fixer in the name of 'Symbion-N', which is a biofertilizer with selective strains of nitrogen fixing bacteria such as Rhizobium, Azospirilum, Acetobacter and Azotobacter is made available from 'T.Stanes and Company Limited', Tamil Nadu, India. Mungbean seeds were bioprimed with 'Symbion-N' @ $10 \mathrm{ml} / \mathrm{kg}$ of 
seeds. Similarly, biopesticides like Beaveria bassiana, Verticilium lecanii and Metarhizium anisopliae were also obtained from 'T.Stanes and Company Limited', Tamil Nadu, India in the name of 'Bio Power', 'Bio Catch' and 'Bio Magic' respectively.

Two sprays were carried out at 40 days after sowing (DAS) and 55 DAS. The data on infestation of pod borer complex was recorded from randomly chosen 2 rows of one metre length from each plot on the basis of number of larvae. The data were taken before spraying as a pre count data and subsequently on $3^{\text {rd }}$, $7^{\text {th }}, 10^{\text {th }}$ and $14^{\text {th }}$ days after the spray schedules. Percentage of pod damage by pod borer complex was recorded during harvest at $65^{\text {th }}$ and $75^{\text {th }}$ day after sowing.

Moreover, different biochemical parameters of mungbean leaf were studied to assess the impact of bio-inoculation of seed and its relationship with pod borer infestation. Fresh leaves were randomly collected from each plot at $40^{\text {th }}$ day after sowing before spray of any biopesticides. Estimation of total phenol and ortho-dihydroxiphenol (OD phenol) was done following the procedure described by Mahadevan and Sridhar (1982). However, protein content of leaf was estimated following Lowry's method (1951). Polyphenol oxidase and peroxidise activity was measured following the procedure described by Mahadevan and Sridhar (1982) and Addy and Goodman (1972) respectively. Correlation studies were also conducted to study the major contributing biochemical parameter(s) along with its impact on pod borer infestation.

Data on number of pod borers in one meter of row length thus obtained were square root transformed $(\sqrt{ } \mathrm{x}+0.5$, where $\mathrm{x}$ is the number of insects) and tested for analysis of variance. Efficiency of each treatment over untreated control was measured through the formula derived by Henderson and Tilton (1955). In case of the percentage pod damage during harvest, the data was angular transformed and tested for analysis for variance. The data on biochemical parameters thus obtained were also tested for analysis of variance. All the analysis was carried over in the statistical software SAS 9.2. The data was computed in Micro-soft Excel.

\section{Results and Discussion}

The efficacy of bio-pesticides on pod borer is depicted in Table 2 which represents the pooled data of two years (2015-2016).

It is clearly revealed that all the treatments were found superior over the check. Initial observation at 40 days after sowing (pre-spray count) showed comparatively less infestation of the pod borers in treatment $\mathrm{T}_{1}$ and $\mathrm{T}_{3}$ recording 1.78 and 1.88 number of pod borer/one metre of row length respectively, which was at par with other five treatments except treatment $T_{2}$ and untreated check $\left(\mathrm{T}_{7}\right)$. In both the treatments $\mathrm{T}_{1}$ and $\mathrm{T}_{3}$, Pseudomonas fluorescence was used for priming of seeds. There was a decreasing trend in number of pod borers in four treatments out of six, which were treated with biopesticides $\left(T_{1}\right.$ to $\left.T_{4}\right)$ upto 10 days after spraying. However, the lowest number of pod borer was found in the treatment $T_{1}$ recording 0.62/one metre of row length at 14 days after spraying of Beauveria bassiana and Verticillium lecanii. It was at par with the treatment $\mathrm{T}_{3}$ (0.64/one metre row length) involving the same biopesticides. These two treatments were found superior than all other treatments. Highest number of pod borer except untreated check were observed in treatment $\mathrm{T}_{2}$ (1.16/one metre row length) at 14 days after spraying of Metarhizium anisopliae and Verticillium lecanii. The percentage control was found highest in treatment $\mathrm{T}_{1}$ and T3 with Beauveria bassiana and Verticillium lecanii, which ranges from 74.4 to $75.02 \%$. 
Moreover, all the treatments significantly reduced the damage of pods by pod borer complex as compared to untreated control, which ranged from $7.03 \%$ to $11.86 \%$. The percentage pod damage was found lowest in treatment $\mathrm{T}_{3}(7.03 \%)$, which was at par with treatment $\mathrm{T}_{1}(7.82 \%)$. The results obtained from the experiment are in clear conformity of earlier works, where good field level control of Helicoverpa armigera and Maruca testulalis was achieved through Beauveria bassiana, Verticillium lecanii and Metarhizium anisopliae (Bayu and Prayogo, 2018; Choudhary et al., 2017; Knox et al., 2016; Revathi et al., 2011). Moreover, seed priming with Pseudomonas fluorescence along with foliar application of Beauveria bassiana is also very effective to control pod borer complex (Soundararajan and Chitra, 2011).

Bio-chemical parameters of plants are related with the defence mechanisms of the plant against its herbivores. Thus, an attempt has been made to study the effect of bio inoculated mungbean on incidence of pod borer and its relation with biochemical parameters of plants. Phenol, OD phenol, peroxidase, polyphenol oxidase and protein of mungbean leaf was studied and presented in Table 3.

The results of the experiment revealed that there is a marked difference in the phenol content in the different treatments. The highest phenol content was found in the treatment $T_{1}$ $(2.472 \mathrm{mg} / \mathrm{g}$ of fresh leaf), which was followed by treatment $\mathrm{T}_{3}(2.218 \mathrm{mg} / \mathrm{g}$ of fresh leaf). The treatments $\mathrm{T}_{2}$ and $\mathrm{T}_{4}$ were statistically at par with each other recording phenol content 2.027 and $1.941 \mathrm{mg} / \mathrm{g}$ of fresh leaves respectively. The lowest phenol content was found in the untreated check suggesting that bio-inoculations have induced enhancement of phenol content within the plant system. The studies in the leaf phenol content of different treatments thus elucidates that the best enhancement of phenol content was found in the bio-inoculation with Pseudomonas fluorescence. There is also a significant difference in the OD Phenol content of leaves in different treatments. Similar trend was also observed in case of OD phenol. The higher OD Phenol content was observed in the treatments $\mathrm{T}_{1}$ and $\mathrm{T}_{3}$ having bio-inoculation with Pseudomonas fluorescence resulting 1.012 and $1.008 \mathrm{mg} / \mathrm{g}$ fresh leaves respectively. The lowest enhancement of OD phenol in leaves among the treatments was in $\mathrm{T}_{6}(0.779 \mathrm{mg} / \mathrm{g}$ fresh leaves), where only nitrogen fixers were used as seed dresser. However, the highest polyphenol oxidase activity $(0.769 \delta$ $495 / \mathrm{mint} . / \mu \mathrm{g}$ protein) was observed in the treatment with $\mathrm{T}_{4}$ having bio-inoculation with nitrogen fixer and azotobacter. This was followed by $\mathrm{T}_{1}$ (PSB, rhizobium and Pseudomonas fluorescence) recording 0.726 $\delta-495 / \mathrm{mint} . / \mu \mathrm{g}$ protein, which was at par with treatment $\mathrm{T}_{4}$. Similarly, peroxidase level in all treatments was found significantly higher as compared to check (0.452 $\delta 420 /$ mint. $/ \mu \mathrm{g}$ protein). Highest level of peroxidase was observed in $\mathrm{T}_{1}(1.258 \delta 420 / \mathrm{mint} . / \mu \mathrm{g}$ protein), which was at par with treatment $\mathrm{T}_{3}(1.224$ $\delta 420 / \mathrm{mint} . / \mu \mathrm{g}$ protein). In both the treatments, Pseudomonas fluorescence was used as seed dresser. Therefore, Pseudomonas fluorescence had a clear impact in enhancement of plant secondary metabolites like phenol, OD phenol, peroxidise and polyphenol oxidase level in mungbean plant. However, there was not much variation in the protein content among the different treatments. The protein content varied from 17.378 to $17.749 \mathrm{mg} / \mathrm{g}$ of fresh leaves. Treatments $T_{1}, T_{2}$ and $T_{3}$ were at par with each other. The protein content of the untreated check $(17.400 \mathrm{mg} / \mathrm{g}$ of fresh leaves) was statistically at par with treatments $T_{4}, T_{5}$ and $\mathrm{T}_{6}$. 
Table.1 Details of the treatments

\begin{tabular}{|c|c|}
\hline $\begin{array}{l}\text { Treatment } \\
\text { Number }\end{array}$ & Details of Treatment \\
\hline T1 & $\begin{array}{l}\text { Seed dressing with Phosphate solubilising bacteria (PSB), Rhizobium }(R h) \text { and } \\
\text { Pseudomonas fluorescence }(P f) @ 5.0 \mathrm{~g} / \mathrm{kg} \text { of seed in } 1: 1 \text { ratio and one spray of } \\
\text { Beauveria bassiana }(\mathrm{Bb}) \text { followed by Verticillium lecanii }(\mathrm{Vl}) @ 5.0 \mathrm{~g} / \mathrm{l} \text { of water }\end{array}$ \\
\hline $\mathbf{T} 2$ & $\begin{array}{c}\text { Seed dressing with Phosphate solubilising bacteria (PSB), Rhizobium and Azotobacter } \\
(A z) @ 5.0 \mathrm{~g} / \mathrm{kg} \text { of seed in } 1: 1 \text { ratio and one spray of Metarhizium anisopliae }(\mathrm{Ma}) \\
\text { followed by Verticillium lecanii @ } 5.0 \mathrm{~g} / \mathrm{l} \text { of water }\end{array}$ \\
\hline T3 & $\begin{array}{c}\text { Seed dressing with Nitrogen fixer }(\mathrm{Nf}) @ 10 \mathrm{ml} / \mathrm{kg} \text { of seed and Pseudomonas } \\
\text { fluorescence @ 5.0 g/kg of seed and one spray of Beauveria bassiana followed by } \\
\text { Verticillium lecanii @ } 5.0 \mathrm{~g} / \mathrm{l} \text { of water }\end{array}$ \\
\hline $\mathbf{T 4}$ & $\begin{array}{c}\text { Seed dressing with Nitrogen fixer @ 10 ml/ } / \mathrm{kg} \text { of seed and Azotobacter @ } 5.0 \mathrm{~g} / \mathrm{kg} \text { of } \\
\text { seed and one spray of Metarhizium anisopliae followed by Verticillium lecanii @ } 5.0 \mathrm{~g} / 1 \\
\text { of water }\end{array}$ \\
\hline T5 & $\begin{array}{c}\text { Seed dressing with Phosphate solubilising bacteria (PSB) and Rhizobium @ } 5.0 \mathrm{~g} / \mathrm{kg} \text { of } \\
\text { seed in 1: } 1 \text { ratio and one spray of Beauveria bassiana followed by Metarhizium } \\
\text { anisopliae @ } 5.0 \mathrm{~g} / \mathrm{l} \text { of water }\end{array}$ \\
\hline T6 & $\begin{array}{c}\text { Seed dressing with Nitrogen fixer @ 10ml/kg of seed and one spray of Beauveria } \\
\text { bassiana followed by Metarhizium anisopliae @ } 5.0 \mathrm{~g} / \mathrm{l} \text { of water }\end{array}$ \\
\hline T7 & $\begin{array}{c}\text { Control Plot as Check where no seed dressing with bioinoculant was done and water was } \\
\text { sprayed only }\end{array}$ \\
\hline
\end{tabular}

Table.2 Efficacy of bio-inoculum and bio-pesticides against pod borer complex

\begin{tabular}{|c|c|c|c|c|c|c|c|}
\hline \multirow[t]{2}{*}{ Treatment } & \multicolumn{5}{|c|}{ No. of larvae/one metre row } & \multirow{2}{*}{$\begin{array}{c}\% \\
\text { Control } \\
\text { at } 14 \\
\text { DAS }\end{array}$} & \multirow{2}{*}{$\begin{array}{c}\% \text { Pod } \\
\text { damage } \\
\text { (average of } \\
\text { two } \\
\text { harvest) }\end{array}$} \\
\hline & $\begin{array}{c}\text { Pre-Spray } \\
\text { at } 40^{\text {th }} \\
\text { Day }\end{array}$ & 3DAS & $7 \mathrm{DAS}$ & $\begin{array}{c}10 \\
\text { DAS }\end{array}$ & $\begin{array}{c}14 \\
\text { DAS }\end{array}$ & & \\
\hline $\begin{array}{c}\mathrm{T}_{1}(P S B+R h+P f+ \\
B b+V l)\end{array}$ & $\begin{array}{c}1.78 \\
(1.51)^{*}\end{array}$ & $\begin{array}{c}1.08 \\
(1.26)\end{array}$ & $\begin{array}{c}0.73 \\
(1.11)\end{array}$ & $\begin{array}{c}0.56 \\
(1.03)\end{array}$ & $\begin{array}{c}0.62 \\
(1.06)\end{array}$ & 74.44 & $\begin{array}{c}7.82 \\
(16.24)^{* *}\end{array}$ \\
\hline $\begin{array}{c}\mathrm{T}_{2}(P S B+R h+A z \\
+M a+V l)\end{array}$ & $\begin{array}{c}2.43 \\
(1.71)\end{array}$ & $\begin{array}{c}1.84 \\
(1.53)\end{array}$ & $\begin{array}{c}1.19 \\
(1.30)\end{array}$ & $\begin{array}{c}1.08 \\
(1.26)\end{array}$ & $\begin{array}{c}1.16 \\
(1.29)\end{array}$ & 64.97 & $\begin{array}{l}11.86 \\
(20.14)\end{array}$ \\
\hline $\begin{array}{c}\mathrm{T} 3(N f+P f+B b+ \\
V l)\end{array}$ & $\begin{array}{c}1.88 \\
(1.54)\end{array}$ & $\begin{array}{c}1.20 \\
(1.30)\end{array}$ & $\begin{array}{c}0.66 \\
(1.08)\end{array}$ & $\begin{array}{c}0.63 \\
(1.06)\end{array}$ & $\begin{array}{c}0.64 \\
(1.07)\end{array}$ & 75.02 & $\begin{array}{c}7.03 \\
(15.38)\end{array}$ \\
\hline $\begin{array}{c}\mathbf{T}_{4}(N f+A z+M a+ \\
V l)\end{array}$ & $\begin{array}{c}1.91 \\
(1.55)\end{array}$ & $\begin{array}{c}1.24 \\
(1.32)\end{array}$ & $\begin{array}{c}0.74 \\
(1.11)\end{array}$ & $\begin{array}{c}0.63 \\
(1.06)\end{array}$ & $\begin{array}{c}1.13 \\
(1.28)\end{array}$ & 56.59 & $\begin{array}{c}9.94 \\
(18.38)\end{array}$ \\
\hline $\begin{array}{c}\mathrm{T}_{5}(P S B+R h+B b \\
+M a)\end{array}$ & $\begin{array}{l}1.95 \\
(1.57)\end{array}$ & $\begin{array}{c}0.99 \\
(1.22)\end{array}$ & $\begin{array}{c}0.48 \\
(0.99)\end{array}$ & $\begin{array}{c}0.75 \\
(1.12)\end{array}$ & $\begin{array}{c}1.13 \\
(1.28)\end{array}$ & 57.48 & $\begin{array}{c}8.62 \\
(17.07)\end{array}$ \\
\hline $\mathbf{T}_{6}(N f+B b+M a)$ & $\begin{array}{c}2.00 \\
(1.58)\end{array}$ & $\begin{array}{c}1.06 \\
(1.25)\end{array}$ & $\begin{array}{c}0.59 \\
(1.04)\end{array}$ & $\begin{array}{c}0.78 \\
(1.13)\end{array}$ & $\begin{array}{l}1.18 \\
(1.30)\end{array}$ & 56.71 & $\begin{array}{c}9.47 \\
(17.92)\end{array}$ \\
\hline $\begin{array}{l}\mathbf{T}_{7} \text { (Untreated } \\
\text { Control) }\end{array}$ & $\begin{array}{l}3.50 \\
(2.00)\end{array}$ & $\begin{array}{l}3.65 \\
(2.04)\end{array}$ & $\begin{array}{c}3.92 \\
(2.10)\end{array}$ & $\begin{array}{c}4.24 \\
(2.18)\end{array}$ & $\begin{array}{c}4.77 \\
(2.30)\end{array}$ & - & $\begin{array}{l}21.58 \\
(27.68)\end{array}$ \\
\hline CD at $5 \%$ & 0.16 & 0.14 & 0.15 & 0.18 & 0.20 & & 2.31 \\
\hline $\operatorname{SEm}( \pm)$ & 0.07 & 0.06 & 0.06 & 0.08 & 0.09 & & 0.74 \\
\hline
\end{tabular}

*Figure in parentheses are square root transformed value, ** Figure in parentheses are angular transformed value, DAS : Days after spraying 
Table.3 Biochemical parameters of mungbean leaf

\begin{tabular}{|c|c|c|c|c|c|}
\hline Treatment & $\begin{array}{c}\text { Total phenol } \\
\text { (mg/gm. of fresh } \\
\text { leaves) }\end{array}$ & $\begin{array}{l}\text { OD phenol } \\
\text { (mg/gm. of } \\
\text { fresh } \\
\text { leaves) }\end{array}$ & $\begin{array}{c}\text { PPO ( } \delta- \\
495 / \text { mint./ } \\
\mu g \\
\text { protein) }\end{array}$ & $\begin{array}{l}\text { Peroxidase } \\
(\delta 420 / \text { mint./ } \\
\mu \mathrm{g} \text { protein })\end{array}$ & $\begin{array}{c}\text { Protein } \\
\text { mg/gm. of } \\
\text { fresh } \\
\text { leaves }\end{array}$ \\
\hline $\begin{array}{c}\mathrm{T}_{1}(P S B+R h+P f \\
+B b+V l)\end{array}$ & 2.472 & 1.012 & 0.726 & 1.258 & 17.697 \\
\hline $\begin{array}{c}\mathrm{T}_{2}(P S B+R h+A z \\
+M a+V l)\end{array}$ & 2.027 & 0.933 & 0.574 & 1.076 & 17.672 \\
\hline $\begin{array}{c}\mathrm{T} 3(N f+P f+B b+ \\
V l)\end{array}$ & 2.218 & 1.008 & 0.672 & 1.224 & 17.749 \\
\hline $\begin{array}{c}\mathrm{T}_{4}(N f+A z+M a+ \\
V l)\end{array}$ & 1.941 & 0.832 & 0.769 & 1.056 & 17.410 \\
\hline $\begin{array}{c}\mathrm{T}_{5}(P S B+R h+B b \\
+M a)\end{array}$ & 1.526 & 0.812 & 0.436 & 0.593 & 17.378 \\
\hline $\mathrm{T}_{6}(N f+B b+M a)$ & 1.504 & 0.779 & 0.463 & 0.678 & 17.433 \\
\hline $\begin{array}{l}\mathbf{T}_{7} \text { (Untreated } \\
\text { Control) }\end{array}$ & 1.208 & 0.629 & 0.431 & 0.452 & 17.413 \\
\hline CD at $5 \%$ & 0.125 & 0.021 & 0.067 & 0.055 & 0.076 \\
\hline $\operatorname{SEm}( \pm)$ & 0.041 & 0.070 & 0.029 & 0.017 & 0.026 \\
\hline
\end{tabular}

The correlation studies between infestation level of pod borers with biochemical parameters of mungbean leaf like total phenol, OD phenol, peroxidase, polyphenol oxidase and protein showed a significant negative relationship between the OD Phenol content with pod borer infestation having correlation coefficient 0.76 at $5 \%$ level of significance.

Therefore, higher OD phenol content in leaf of mungbean plant through seed bio inoculation had adversely affected the population build up of pod borers. The corresponding regression equation showed as $4.99-4.12 \mathrm{x}$, where $\mathrm{x}$ represents the number of pod borers in one meter row length. The coefficient of regression $\left(\mathrm{R}^{2}\right)$ was found as 0.67 which simply means that OD phenol contributed $67 \%$ variation in population build up of pod borers in mungbean crop. Similar findings were observed by many research workers. Pseudomonas fluorescence is capable of enhancing the level of phenolics and defense related enzyme activities in plants, thus imparting induced resistance against Helicoverpa armigera (Jeyarani et al., 2005; Rajendran et al., 2007; Muthukumaran, 2016). Therefore, it can be concluded that Pseudomonas fluorescence, the most effective bio-inoculant may be used in pre-sowing seed priming of mungbean to enhance the secondary plant metabolites in the plant system for imparting resistance to some extent against the pod borer complex. Moreover, biopesticides like Beauveria bassiana and Verticillium lecanii may be applied at 15 days interval starting from 40 days of crop age to get effective control of pod borer complex in mungbean crop.

\section{References}

Addy, S. K., and Goodman, R. N. 1972. Polyphenol oxidase and peroxidase activity in apple leaves inoculated with a virulent or an avirulent strain of Erwinia amylovora. Indian Phytopathology. 25: 575-579. 
Anonymous, 2018. Pulses revolution from food to nutritional security. Published by Crop Division, Department of Agriculture, Cooperation and Farmers Welfare, Ministry of Agriculture and Farmers Welfare, Government of India, New Delhi., pp 1-94.

Bayu, M. S. Y. I., and Prayogo, Y. 2018. Field efficacy of entomopathogenic fungi Beauveria bassiana (Balsamo.) for the management of mungbean insect pests. International Symposium of Food and Agro-biodiversity Conference Series. Earth and Environmental Science. 102: 012032.

Bhowmick, M. K., R. Sadhukhan and Saha, P. K. 2008. Response of new mungbean genotypes to sowing time during spring-summer in West Bengal. Journal of Crop and Weed. 4(1): 1-3.

Choudhary, R., A. Kumar, G. C. Jat, Vikram, Deshwal, H. L. 2017. Comparative efficacy of certain biopesticides against tomato fruit borer Helicoverpa armigera (Hub.). International Journal of Current Microbiology and Applied Sciences. 6(8): 1068-1081.

Duraimurugan, P., and Tyagi, K. 2014. Pest spectra and its yield losses in mungbean and urdbean under changing climate scenario. Legume Research. 37(2): 212-222.

Henderson, C. F., and Elvin, W. T. 1955. Test with acaricides against brown wheat mite. Journal of Economic Entomology. 48(2): 157-161.

Jeyarani, S., N. Sathiah and Karuppuchamy, P. 2005. Influence of Pseudomonas fluorescens and a Nuclepolyhedro virus on cotton bollworm Helicoverpa armigera (Hubner). Tropical Agricultural Research. 17: 221-230.

Knox, O. G. G., C. M. T. Anderson, J. L. Ross, C. C. R. Tann and Gupta, V. V. S. R. 2016. Organisms with potential to assist in control of Helicoverpa armigera in Australian cotton production system. Crop and Pasture Science. (http://dx.doi.org/10.1071/CP16270).

Lal, S. S., 1985. A review of insect pests of mungbean and their control in India. Tropical Pest Management. 31(2): 105-114.

Lowry, O. H., N. J. Rosebrough, A. L. Farr and Randal, R. J. 1951. Protein measurement with folin phenol reagent. Journal of Biological Chemistry. 193(1): 265-275.

Mahadevan, A., and Sridhar, R. 1982. Methods in Physiological Plant Pathology. Sivakami Publication, Madras. 159 pp.

Mahmood, I., S. R. Imadi, K. Shazadi, A. Gul and Hakeem, K. R. 2016. Effects of pesticides on environment, In : Hakeem K, M. Akhtar and S. Abdullah (eds) Plant, Soil and Microbes (vol.1). Springer International Publishing. Switzerland. pp 253-269.

Maina, U. M., I. B. Galadina, F. M. Gambo, and Zakaria D. 2017. A review of use of entomopathogenic fungi in the management of insect pests of field crops. Journal of Entomology and Zoology Studies. 6(1): 27-32.

Murugan, M., and Dhandapani, N. 2007. Induced systemic resistance activates defense responses to interspecific infestation on tomato. Journal of Vegetable Science. 12(3): 43-62.

Muthukumaran, N. 2016. Biophysical and biochemical factors of resistance in tomato accessions as influenced by selected bioinoculants against fruit worms Helicoverpa armigera (Hubner). International Journal of Current Microbiology and Applied Sciences. 5: 252-262.

Nair, R. M., R. Yu Yang, W. J. Easdown, D. Thavarajah, P. Thavarajah, J. d'A Hughes and Keatinge, J. D. H. 2013. 
Biofortification of mungbean (Vigna radiata) as a whole food to enhance human health. Journal of the Science of Food and Agriculture. 93: 18051813.

Pangesti, N., S. Vandenbrande, A. Pineda, M. Dicke, J. M. Raaijmakers and Van Loon, J. J. A. 2017. Antagonisim between two root-associated beneficial Pseudomonas strains does not affect plant growth promotion and induced resistance against a leaf-chewing herbivore. FEMS Microbiology Ecology. 93:4. 1-8.

Park, M., C. Kim, J. Yang, H. Lee, W. Shin, S. $\mathrm{Kim}$ and $\mathrm{Sa}, \mathrm{T}$. 2005. Isolation and characterization of diazotrophic growth promoting bacteria from rhizosphere of agricultural crops of Korea. Microbiological Research. 160: 127-133.

Pataczek, L., Z. A. Zahir, M. Ahmad, S. Rani, R. Nair, R. Schafleitner, G. Cadisch and Higler, T. 2018. Beans with benefits - the role of mungbean (Vigna radiata) in a changing environment. American Journal of Plant Sciences. 9: 1577-1600.

Rajendran, N., R. Samiyappan, T. Raghuchander and Saravanakumar, D.
2007. Endophytic bacteria mediate plant resistance against cotton bollworm. Journal of Plant Interactions. 2:1, 1-10.

Rashid, M H, and Chung, Y. R. 2017. Induction of systemic resistance against insect herbivores in plants by beneficial soil microbes. Frontiers in Plant Science. 8: 1816.

Revathi, N., G. Ravikumar, M. Kalaiselvi, D. Gomathi and Uma, C. 2011. Pathogenicity of three entomopathogenic fungi against Helicoverpa armigera. Journal of Plant Pathology and Microbiology. 2: 114.

Singh, A. K., S. S. Singh, V. Prakash, S. Kumar and Dwivedi, S. K. 2015. Pulses production in India: Present status, bottleneck and way forward. Journal of AgriSearch. 2(2): 75-83.

Soundararajan, R. P., and Chitra, N. 2011. Effects of bioinoculants on sucking pests and pod borer complex in urdbean. Journal of Biopesticides. 4(1): 7-11.

Umbarkar, P. S., G. J. Parsana and Jethva, D. M. 2010. Estimation of yield losses by pod borer complex in greengram. Legume Research. 34(4): 308-310.

\section{How to cite this article:}

Snehangshu Das, Swarnali Bhattacharya and Tapamay Dhar. 2019. Combination of Plant Growth Promoting Rhizobacteria and Biopesticides: An Effective Means of Suppressing Pod Borer Complex in Mungbean. Int.J.Curr.Microbiol.App.Sci. 8(11): 1410-1417. doi: https://doi.org/10.20546/ijcmas.2019.811.165 